\title{
Optimization of Magenta Dye Decolorization Different Parameters by Citrobacter sp.
}

\author{
Shankara $\mathbf{S}^{\mathbf{1}^{*}}$, Vijayakumar M. $\mathbf{H}^{2}$, Kotresha $\mathrm{D}^{3}$, Gaddad S. $\mathbf{M}^{4}$ \\ ${ }^{1}$ Department of Microbiology, Government College for Women, Chintamani-563 125, Karnataka, India \\ ${ }^{2}$ Department of Biochemistry, Gulbarga University, Gulbarga-585106, Karnataka, India
}

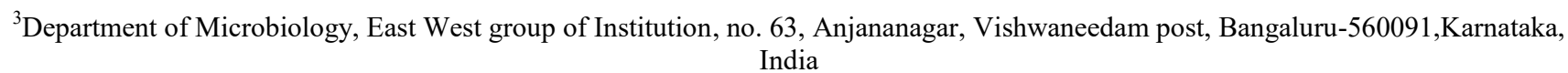

${ }^{4}$ Department of Microbiology, Gulbarga University, Gulbarga-565 106, Karnataka, India

\begin{abstract}
A thermo-alkalophilic bacterium Citrobacter sp. isolated from textile mill effluent sample as a decolouring microorganism. The maximum $500 \mathrm{mg} \mathrm{L}^{-1}$ Magenta (Basic Red-9) dye decolorization was takes place in 48 h and completely decolorizes the dye Magenta up to a maximum concentration $1000 \mathrm{ppm}$, however the time taken was $104 \mathrm{~h}$. The optimum physical parameters such as temperature $40^{\circ} \mathrm{C}, \mathrm{pH} 8.0$ and $2.5 \%(w / v)$ of nitrogen source were required for the decolorization of Magenta dye by Citrobacter sp.Effect of seven different metal ions on decolorization of Magenta tested, in which most toxic was Cadmium and less toxic was Lead at 0.05 mM concentration. The curing study indicates that decolorization was takes place by enzyme which was plasmid mediated. The degraded dye metabolites are analyzed by TLC and diazotization, carbylamines test for individual metabolite indicates biotransformation of Magenta into aromatic amine and non-toxic aromatic metabolites. These results suggest that the isolated organism Citrobacter sp.as a useful tool to treat waste water containing reactive dyes at static condition.
\end{abstract}

Keywords: Citrobacter sp., Decolorization, Magenta, Metabolite.

\section{Introduction}

Textile dyeing effluents containing recalcitrant dyes are polluting waters due to their color and by the formation of toxic or carcinogenic intermediates, such as aromatic amines from azo dyes[1, 2]. Water plays a vital and essential role in our ecosystem. This natural resource is becoming scarce, makingits availability a major social and economic concern. Use of a large variety of synthetic dyes in textile industries has raiseda hazardous environmental alert. About $17-20 \%$ of freshwater pollution is caused by textile effluents. These effluentsare recalcitrant to biodegradation and cause acute toxicity to the receiving water bodies, as these comprised of varioustypes of toxic dyes, which are difficult to remove[3].The conventional treatment systems based on physical or chemical treatment does not remove the color and dye compound concentration[4].

The decolorization of the dye takes place either by adsorption on the microbial biomass or biodegradation by the cells and bioremediation takes place by anaerobic and/or aerobic process. Biological methods are currently viewed as specific, less energy intensive, effective, environmentally safe and they result in partial or complete bioconversion of organic pollutants to stable and nontoxic end products $[4,5]$. The products of intermediate metabolism during the decolorization process, such as aromatic amines, can be degraded by the hydroxylase and oxygenase produced by bacteria [5,6].In this study, a thermo-alkalophilic bacterium Citrobacter sp. capable of decolorizing Magenta and the effects of various physical and chemical parameters on dye decolorization were investigated.

\section{Materials and Methods}

\section{Dye decolorization studies}

Decolorizing activity is expressed in terms of percentage of decolorization of the dye [7].

$\mathrm{D}=\left[\left(\mathbf{A}_{\mathbf{0}}-\mathbf{A}_{\mathbf{1}}\right) / \mathbf{A}_{\mathbf{0}}\right] \times \mathbf{1 0 0}$

Where, $\mathrm{D}, \%$ of decolorization; $\mathrm{A}_{0}$, initial absorbance; $\mathrm{A}_{1}$, final absorbance

The effect of Dye concentration, temperature, $\mathrm{pH}$ and Nitrogen source on dye decolorization

The $250 \mathrm{~mL}$ Erlenmeyer flasks having $100 \mathrm{~mL}$ of $\mathrm{MM}$ medium containing 100 ppm of dye were inoculated with selected bacterium. The flasks were incubated at various temperatures ranging from $20-60^{\circ} \mathrm{C}$ and the effect of $\mathrm{pH}$ on dye decolorization was studied with various $\mathrm{pH}$ values ranging from 5-9. The effect of Nitrogen source and dye on dye decolorization was studied at various concentrations ranging from $1-4 \%(\mathrm{w} / \mathrm{v})$ and $200-1200 \mathrm{ppm}$, respectively. Uninoculated controls were prepared in parallel in all experiments.

\section{Curing}

The Citrobacter sp. was pre-cultured in $\mathrm{BH}$ medium with shaking for $18 \mathrm{~h}$. the pre-culture was inoculated into $5 \mathrm{ml}$ of fresh $\mathrm{BH}$ medium containing $0.5 \mathrm{~mL}$ curing agent (Acridine Orange $1 \%$ ) and incubated for $24 \mathrm{~h}$ at $37^{\circ} \mathrm{C}$. After $24 \mathrm{~h}$ the culture was transferred to fresh $\mathrm{BH}$ medium containing $0.1 \mathrm{~g}$ $\mathrm{L}^{-1}$ of dye, Simultaneously transferred to fresh $\mathrm{BH}$ medium containing $0.5 \mathrm{~mL}$ of $1 \%$ Acridine orange, the process was repeated every $24 \mathrm{~h}$ up to $5 \mathrm{~d}$. The culture was properly diluted with saline and $0.1 \mathrm{~mL}$ of diluted culture was placed on Nutrient agar. The inoculated plate was incubated at 37 ${ }^{\circ} \mathrm{C}$ for $24 \mathrm{~h}$. Each colony appearing on the agar plate was tested for its ability to decolorize the Magenta. The colony 


\section{International Journal of Science and Research (IJSR) \\ ISSN (Online): 2319-7064}

Index Copernicus Value (2015): 78.96 | Impact Factor (2015): 6.391

which did not decolorize the dye is considered as a cured colony. The Curing frequency was calculated by colony counts of the initial one, i.e., the difference between the initial colony counts, $(i)$ and the final colony count $(f)$ of the sample. The curing frequency was calculated by following formula.

Curing frequency $(\%)=$ Colonies $(i)-$ Final $(f) \times 100 /$ Colonies $(i)$

\section{Extraction of Metabolites}

The complete decolorized medium of Magenta was centrifuged at $10,000 \mathrm{rpm}$ for $15 \mathrm{~min}$. The $\mathrm{pH}$ was adjusted to 7 and $200 \mathrm{~mL}$ of the supernatant was extracted twice with $500 \mathrm{~mL}$ diethyl ether. The remaining aqueous layer was acidified to $\mathrm{pH} 2$ by $1 \mathrm{~N} \mathrm{HCl}$ and extracted twice with diethyl ether $(500 \mathrm{~mL})$. The acidic and basic extracted fractions were pooled and evaporated to very small quantity.

\section{Thin layer Chromatography (TLC)}

The glass plate of $200 \times 100 \times 2 \mathrm{~mm}$ (length $\times$ breadth $\times$ thickness) coated with $40 \%(\mathrm{w} / \mathrm{v})$ aqueous slurry of Silica gel $\mathrm{G}$ with binder were used for carrying out TLC, $10 \mu \mathrm{l}$ of extracted fractions were loaded on Silica gel, dried and the solvent system used were propanol : water : acetic acid (90: $9: 1 \mathrm{v} / \mathrm{v})$ for developing the TLC plate. The dye and products on chromatogram was observed by exposing to long wavelength UV-Light $(365 \mathrm{~nm})$ and the metabolites were partially identified by Diazotization and Carbylamine test.

\section{Results and Discussion}

Effect of Dye Concentration, Temperature, pH and Nitrogen source on dye decolorization

Effect of dye concentration (Fig. 1) on the decolorization ability of the bacterium was studied by inoculation of the bacterium to $\mathrm{BH}$ medium supplemented with different concentrations of Magenta (100-1000 ppm). When the effect of different initial dye concentrations of Magenta on decolorization was observed using 100, 200 300, 400, 500, $600,700,800,900$ and $1000 \mathrm{ppm}$ and the required times to reach a maximum decolorization extent were $24,32,40,48$, $48,60,72,72,84$, and $104 \mathrm{~h}$, respectively. These results indicate that as the initial dye concentration increases the time required for complete decolorization also increases and dye concentration above 1000 ppm was not completely decolorized even after extended incubation periods. It was reported that dye decolorization can be strongly inhibited when a high concentration dyestuff was used to examine the poisonous effect of the dye on the degrading microorganisms $[8,9]$.

One of the most important parameters for dye decolorization is temperature. In order to determine the optimum temperature for dye decolorization using Magenta (100 ppm) a temperature range of $20-50^{\circ} \mathrm{C}$ was examined. Fig. 2 shows that the complete dye decolorization increased with increase in temperature from $20-40^{\circ} \mathrm{C}$ and decreases with increase in temperature above the $40^{\circ} \mathrm{C}$, which might be due to the loss of cell viability or deactivation of the enzymes responsible for decolorization $[10,11]$. The $100 \%$ dye decolorization was observed at $40^{\circ} \mathrm{C}$ within $20 \mathrm{~h}$ and temperature between $35-45^{\circ} \mathrm{C}$ was optimum for the removal of Magenta.

The results on the effect of various hydrogen ion concentrations on decolourization of Magenta by Citrobacter sp. are represented in Fig. 3. The maximum decolourization was found to be between $\mathrm{pH}$ 7.0-8.5 within 24-30 h respectively. These results indicated that Citrobacter sp. is capable of decolorizing Magenta (100 ppm) within a wide range of $\mathrm{pH}$ and organism was completely decolourizes $100 \mathrm{ppm}$ of the dye within the $\mathrm{pH}$ range from 6.0 to 10.0. Below $\mathrm{pH} 6.0$ and above $\mathrm{pH} 10.0$ complete decolourization of the Magenta (100 ppm) by Citrobacter sp. was not observed, however optimum $\mathrm{pH}$ was found to be 8.0 for decolourization of Magenta where decolourization occurred within 20 hours of incubation. The $\mathrm{pH}$ tolerance of decolorizing bacteria is quite important because reactive azo dyes bind to cotton fibers by addition or substitution mechanisms under alkaline conditions and at high temperatures [12]. These results indicate that the bacterium Citrobacter sp. was alkalophilic in nature.

Thus the effect of various concentrations $\left(0.25-2.5 \mathrm{~g} \mathrm{~L}^{-1}\right)$ of the nitrogen source (peptone) was investigated and the results are represented in Fig.4.The decolorization of Magenta (100 ppm) along with organic nitrogen though Citrobactersp. was observed. The presence of organic nitrogen source like peptone the rate of color reduction was increased with the concentration of organic nitrogen $0.25 \mathrm{~g}$ $\mathrm{L}^{-1}$ to $2.25 \mathrm{~g} \mathrm{~L}^{-1}$ and above $2.25 \mathrm{~g} \mathrm{~L}^{-1}$ it was constant. Praveenkumar and Bhat, (2012) have reported similar reports of increase in the efficiency of decolorization with increase in the organic nitrogen concentration and many report shows the maximum decolorization of dyes takes place in presence of nitrogen source $[13,14]$ and these investigations pointed nitrogen source was essential for decolorization of reactive dyes.

\section{Effect of heavy metals}

The effect of different heavy metals $(0.025-1 \mathrm{mM})$ on decolourization of Magenta (100 ppm) by Citrobacter sp. was investigated and the results are shown in Fig.5. Out of the seven metals tested cadmium was most toxic. With this metal the incubation time required for $100 \%$ decolourization sharply increased from $24 \mathrm{~h}$ at $0.025 \mathrm{mM}$ to $32 \mathrm{~h}$ at $0.05 \mathrm{mM}$ and further to $72 \mathrm{~h}$ at $0.5 \mathrm{mM}$ and above $0.5 \mathrm{mM}$ complete dye decolourization did not occur even at the extended periods. Similar observations were made with zinc, mercury and copper where complete decolourization of $100 \mathrm{ppm}$ of Magenta occurred after $72 \mathrm{~h}$ incubation up to $0.5 \mathrm{mM}$ of the respective metals and $100 \%$ decolourization could not be achieved above $0.5 \mathrm{mM}$. Contrarily, nickel, lead and cobalt, appeared to be comparatively less toxic and lead appeared to even stimulate and enhance decolourization process at its lower concentrations.

\section{Curing}

Curing of Citrobacter sp. was carried out to determine the location of genes responsible for decolourization. The percentage frequency of curing was found to be $24.42 \%$ on first day and it increased gradually to $90.83 \%$ at $5^{\text {th }}$ d (Fig.6). The plasmid was found to be lost during successive cycles and after $5^{\text {th }} \mathrm{d}$ the dye decolorizing ability of the bacteria was completely lost. This result indicates that the genes for 


\section{International Journal of Science and Research (IJSR) \\ ISSN (Online): 2319-7064 \\ Index Copernicus Value (2015): 78.96 | Impact Factor (2015): 6.391}

due decolourization are present on plasmid andnot on bacterial genome.

\section{Isolation and Identification of metabolites}

The biodegradation products of Magenta were loaded on TLC plate and developed by Propanol: Water: Acetic acid (90: 9: $1^{[7]}$ $\mathrm{v} / \mathrm{v}$ ) solvent system. The developed TLC plate has shown three spots under UV light observation with $\mathrm{R}_{f}$ values of $0.33,0.46$ 0.71 andthe $\lambda_{\max }$ values of the peaks were found at $260 \mathrm{~nm}, 320$ $\mathrm{nm}$ and $280 \mathrm{~nm}$ respectively (Table 1). Further metabolites were characterised by chemical test such as Diazotization and Carbylamines tests. The spot with $\mathrm{R}_{\mathrm{f}}$ values 0.33 and 0.46 are negative to diazotization and carbylamine tests and whereas $R_{f}$ value 0.71 showed positive result for the diazotization and carbylamine tests. These results indicate that our isolated bacterium was potential for the degradation azo dyes and[10] converted into aromatic compounds with and without amine group metabolites.

\section{References}

[1] Hao, O.J., Kim, H., Chiang, P.C. "Decolorization of wastewater". Cri. Rev. Environ. Sci. Technol. 30, 449505,2000 .

[2] Srikanlayanukul M, Wirut K, Takashi W, and Chartchai K. "Decolorization of orange-II by immobilized thermotolerant white rot fungus Coriolusversicolor RC3 in packed-bed bioreactor". Biotechnology, 7:280-286, 2008.

[3] Naik NM, Jagadeesh KS, Alagawadi AR."Microbialdecolorization of spentwash: a review". Indian J Microbiol48:41-48, 2008.

[4] Sarioglu, M., Bali, U., Bisgin, T. "The removal of C.I. Basic Red 46 in a mixed methanogenic anaerobic culture". Dyes Pig.74,223-229, 2007.

[5] Saratale, R.G., Saratale, D., Chang, J.S., Govindwar, S.P.
"Bacterial decolorization and degradation of azo dyes: a review”. J.Taiwan Inst. Chem. Eng.42, 138-157, 2011.

[6] Shah, M.P. "Microbial Degradation of Acid Blue Dye by Mixed Consortium". Int. J. Environ.Bioremed.Biodegrad.2, 125-132, 2014.

7] Yatome C, Maiti KT, Bhattacharyya BC. "Degradation of crystal violet by Nocardiacrallina". Application MicrobiolBiotechnol38:565-569, 1993.

8] Khehra, M.S., Saini, H.S., Sharma, D.K., Chadha, B.S., Chimni, S.S. "Comparative studies on potential of consortium and constituent pure bacterial isolates to decolorize azo dyes". Water Res. 39, 5135-5141, 2005.

] Kalme, S.D., Parshetti, G.K., Jadhav, S.U., Govindwar, S.P. "Biodegradation of benzidine based dye Direct Blue-6 by Pseudomonas desmolyticum NCIM 2112". Biores.Technol. 98, 1405-1410, 2007.

0] Panswad, T., Luangdilok, W. "Decolorization of reactive dyes with different molecular structures under different environmental conditions". Water Res. 34, 4177-4184, 2000.

[11] Cetin, D., Donmez, G."Decolorization of reactive dyes by mixed cultures isolated from textile effluent under anaerobic conditions". Enzyme Microb.Technol. 38, 926930, 2006.

[12] Aksu, Z. "Reactive dye bioaccumulation by Saccharomyces cerevisiae". Process Biochem, 38, 14371444, 2003.

[13] Ponraj, M., Gokila, K., Zambare, V. "Bactarial decolorization of textile dye- orange 3R". Int. J. Advanced Biotech and Resea. (2), 168-177, 2011.

[14] Bhatt, N.S., Vagadiya, D.R., Junnarkar, N.S."Decolorization, degradation and azo-reductase study by bacterial transformation of reactive red HE8b". Int. J. Res. BioSci.1(1), 29-41, 2012.

Table 1: Characterization of Magenta dye degradation products

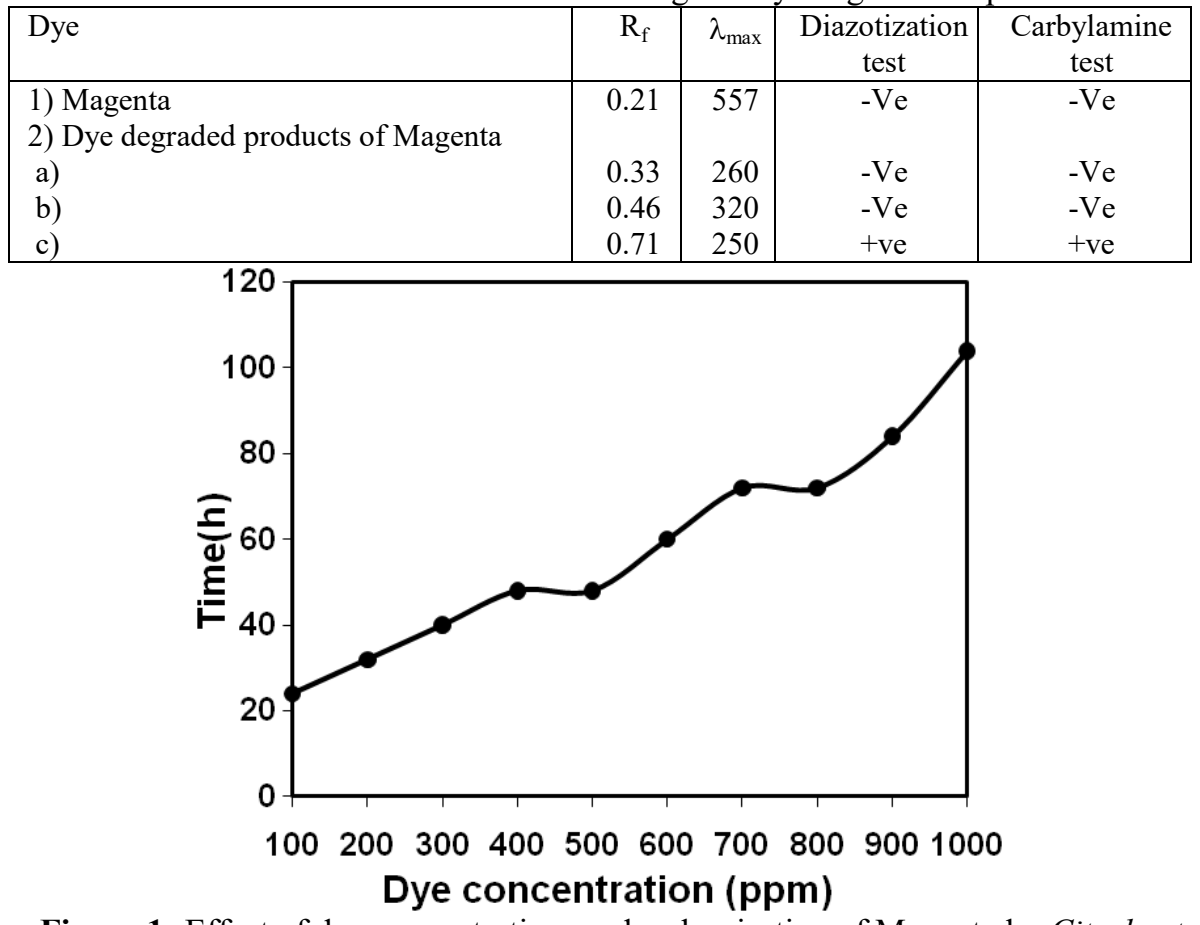

Figure 1: Effect of dye concentration on decolourisation of Magenta by Citrobactesp. 


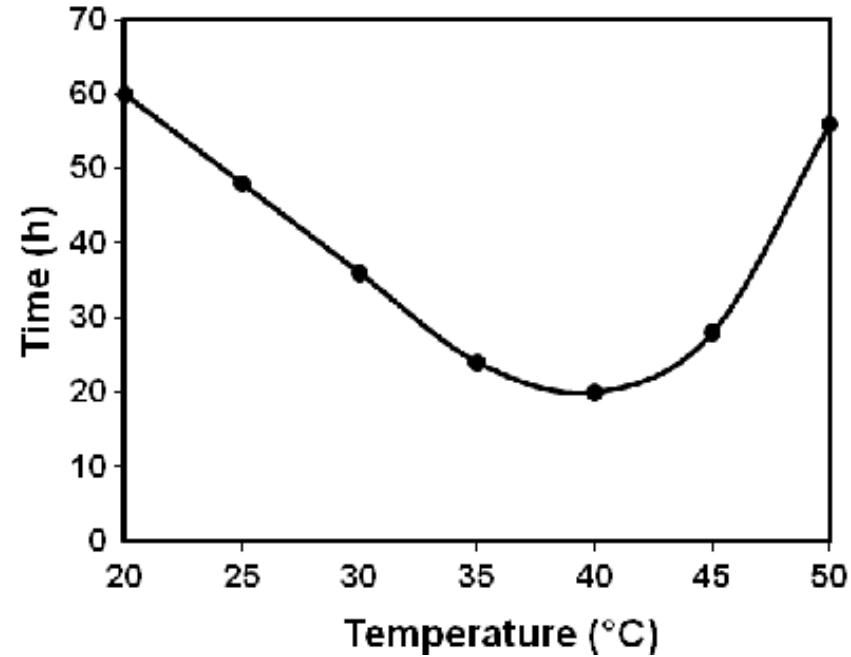

Figure 2: Effect of temperature on decolourisation of Magenta by Citrobacter sp.

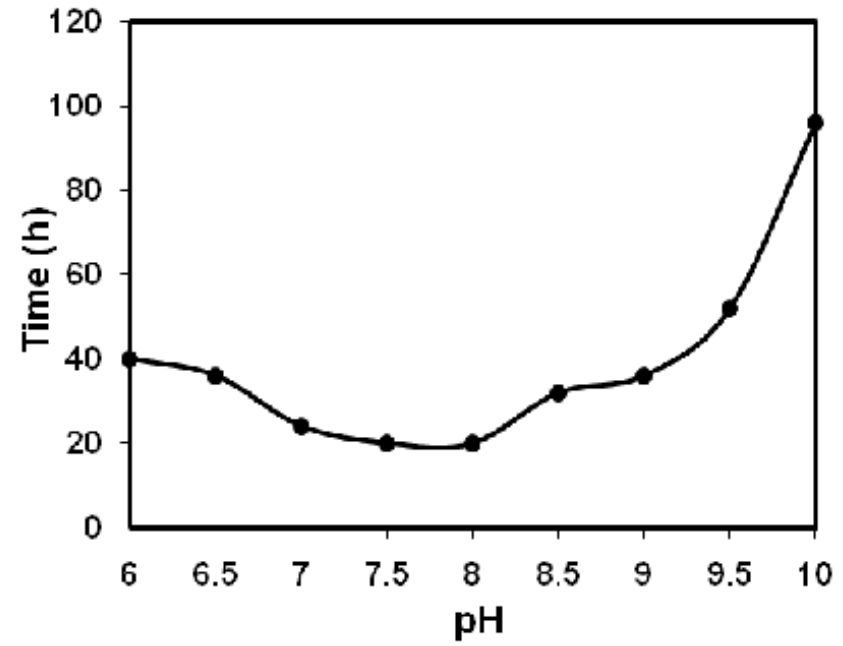

Figure 3: Effect of $\mathrm{pH}$ on decolourisation of Magenta by Citrobacter sp.

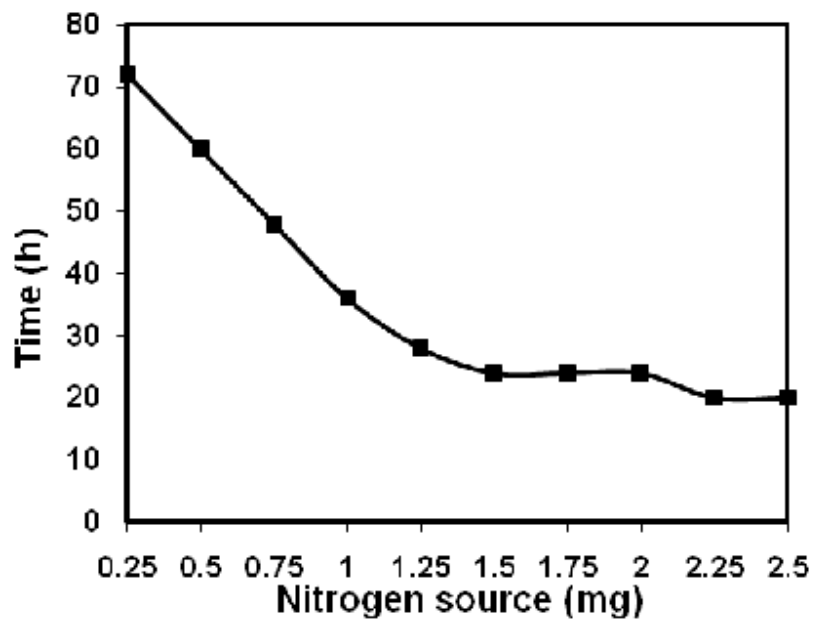

Figure 4: Effect of Nitrogen concentration on decolourisation of Magenta by Citrobacter sp. 


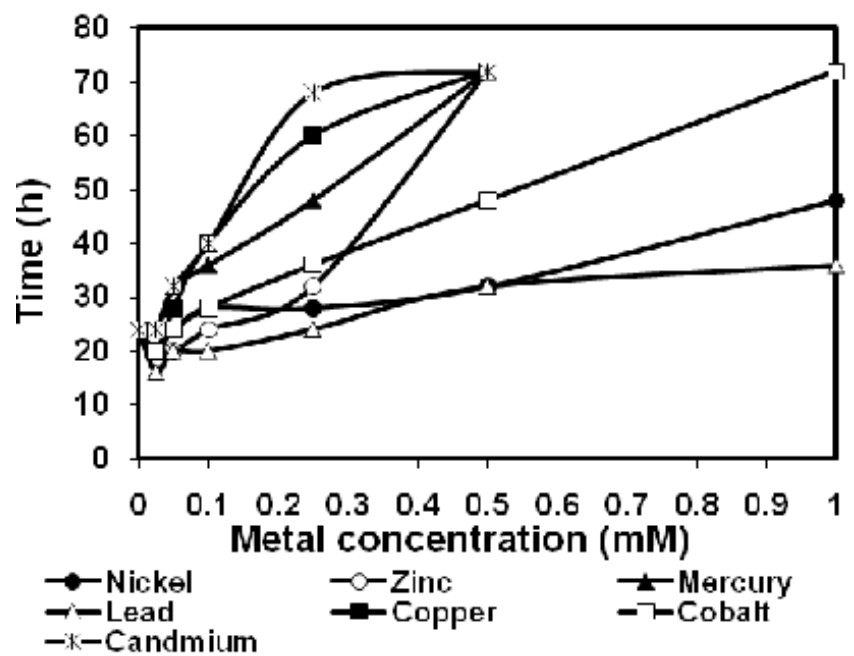

Figure 5: Effect of heavy metals on decolourisation of Magenta by Citrobacter sp.

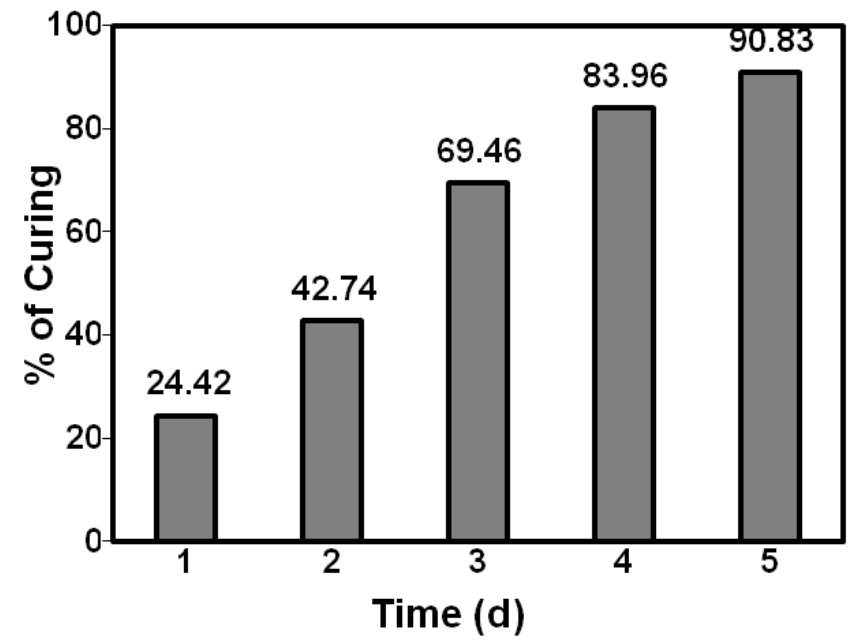

Figure 6: Curing of Citrobactersp with acridine orange for the loss of Magenta decolourising activity 